УДК 628.4:332.1

DOI: https://doi.org/10.26642/jen-2019-4(90)-72-80

О.В. Хандогіна, ст. викладач

Н.Ю. Мущинська, к.е.н., доц.

Харківський національний університет міського господарства імені О.М. Бекетова

\title{
Порівняльна оцінка рівня розвитку системи управління побутовими відходами в регіонах України
}

\begin{abstract}
Організаџія комплексної системи управління з побутовими відходами на регіональному рівні вимагає попередньої оичнки поточної ситуаџії для прийняття зважених рішень. У статті досліджуються особливості розвитку такої системи в регіонах України на основі удосконаленоі методологї BiPRO. Проведено аналіз за чотирма групами показників, які характеризують такі аспекти: відповідність поточної ситуаџії принципам ієрархї методів поводження з відходами, наявність та ефективність економічних інструментів, існування належної мережі об'єктів поводження з відходами, зменшення частки захоронення відходів, що біологічно розкладаються. Встановлено, що найбільш ефективною система управління відходами $\epsilon$ в Тернопільській, Київькій та Миколаївській областях. Найгірма ситуачія склалася в Херсонській, Житомирській, Запорізькій та Одеській областях. В иілому система управління побутовими відходами в Україні знаходиться на невисокому рівні. Найбільш проблемними є питання створення сучасних об'єктів поводження з відходами - потужностей оброблення та перероблення, сучасних екологічно безпечних місць видалення відходів, а також питання охоплення населення послугами зі збирання відходів. Удосконалення системи управління відходами має забезпечуватися шляхом ефективного та раціонального планування й прогнозування основних показників сфери поводження з відходами та їх відображення в регіональних програмах та планах, розвитком сучасних технологій та інфраструктури оброблення і перероблення відходів, збалансуванням фінансово-економічних механізмів тощо.
\end{abstract}

Ключові слова: регіональний розвиток; управління побутовими відходами; індикатори; методика оиінки.

Актуальність теми. Питання управління побутовими відходами є однією з найважливіших проблем, 3 якою на даний час зіштовхуються всі регіони України. Ситуація в цій сфері, що склалася в країні, $\epsilon$ критичною та характеризується загрозами сталому розвитку держави, екологічній безпеці, життю та здоров’ю населення, виведенням 3 обігу цінних енергетичних та матеріальних ресурсів. Стратегічними завданнями організації системи поводження з відходами є впровадження системного підходу до даного питання на державному та регіональному рівнях. Разом з тим, диспропорції у соціально-економічному розвитку регіонів, відсутність до недавнього часу чіткої та послідовної державної політики щодо поводження 3 побутовим відходами, непрозорість фінансових механізмів тощо обумовлюють нерівномірність розвитку регіональних систем поводження 3 відходами, що врешті-решт спричиняє розбалансування на національному рівні.

Аналіз останніх досліджень та публікації, на які спирається автор. Впровадження адекватних та ефективних заходів щодо організації комплексної системи управління 3 побутовими відходами на рівні регіонів потребує попередньої оцінки поточної ситуації для прийняття зважених рішень. Вивчення різних підходів до оцінки розвитку регіонів чи територій за різними показниками проводили такі вчені, як D.Wilson, L.Rodich [1, 2], V.Sanjeevi, P.Shahabudeen [3], J.T Kirkeby, T.L. Hansen [4], D.E.T. Cervantes A.L. Martínez, [5] С. П. Іванюта та А. Б. Качинський [6], А.А. Коваленко [7], М.С. Самойлік, П.В. Писаренко, Л.А. Колєснікова [8], М.І. Стегней та А.-М.I. Архангельська [9], І.А. Островський, С.Ю. Юр'єва, О.П. Коюда, О.І. Славута [10] та інші. В багатьох з них порушуються питання поводження 3 відходами, що $є$ невід'ємним компонентом екологічної безпеки регіонів та держави в цілому. Кривенко С.В. [11] наголошує, що поводження з відходами в Україні має несистемний характер, а при трансформації розрізнених елементів у систему важливу роль мають і повинні відігравати регіони як «системоутворюючі провідники». Однак питання дослідження регіональних особливостей у сфері управління відходами на сьогодні лишається недостатньо вивченим та потребує уваги, особливо в умовах реформування, яке фактично почалося з прийняття в 2017 році Національної стратегії управління відходами до 2030 року [12].

Метою статті є оцінка та порівняння рівня розвитку системи управління побутовими відходами в регіонах України.

Викладення основного матеріалу. В статті проведено оцінку рівня розвитку системи управління відходами для 24 областей України (за виключенням АР Крим через відсутність даних). Джерелом вихідної інформації є звітність «Санітарна очистка», яка щорічно публікується Міністерством розвитку громад та територій України (раніше - регіонального розвитку, будівництва та житлово-комунального 
господарства) [13, 14], нормативно-правові документи $[12,15]$, регіональні програми поводження 3 побутовими відходами $[16,17]$, інші документи [18] тощо. Методологічну основу складає вдосконалена автором методика оцінки ефективності системи управління відходами [19-21]. Значення кожного 3 критеріїв відповідно до оригінальної методики переводилось в бали (0, 1 чи 2). Порогові значення показників для присвоєння балів були скориговані з урахуванням цільових показників, вказаних у Національній стратегії управління відходами до 2030 року [12] або фактичних показників системи управління відходами в Україні та вказані в таблиці з результатами оцінки.

Основні індикатори та результати оцінювання наведені в таблиці 1.

Табличя 1

Оиінка системи управління твердими побутовими відходами (ТПВ) в регіонах Украйни

\begin{tabular}{|c|c|c|c|c|c|c|c|c|c|c|c|c|c|c|c|c|c|c|c|c|c|c|c|c|c|}
\hline \multirow[b]{2}{*}{ Індикатор } & \multicolumn{25}{|c|}{ Області } \\
\hline & 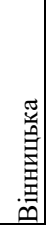 & 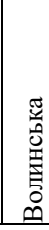 & 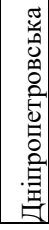 & 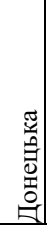 & 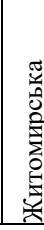 & 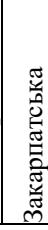 & 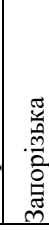 & 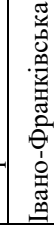 & 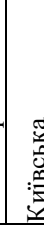 & & 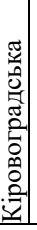 & 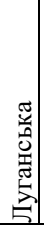 & 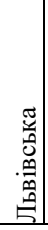 & 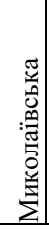 & \begin{tabular}{l}
$\pi$ \\
\multirow{3}{0}{} \\
0 \\
0 \\
0 \\
0
\end{tabular} & 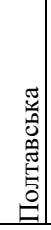 & 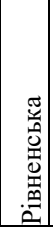 & 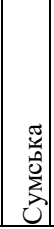 & 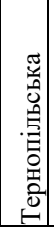 & 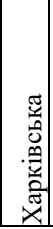 & 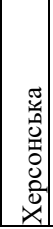 & 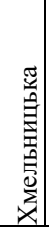 & 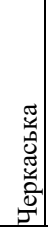 & 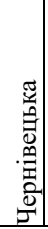 & 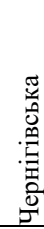 \\
\hline \multicolumn{26}{|c|}{$\begin{array}{cc}1 . & \text { Відповідність реальної ситуації принципам ієрархії методів поводження з відходами } \\
\end{array}$} \\
\hline $\begin{array}{l}\text { 1.1. Рівень розриву між } \\
\text { захороненням ТПВ та рівнем } \\
\text { економічного розвитку регіонів }\end{array}$ & 1 & 0 & 1 & 1 & 0 & 0 & 0 & 0 & 1 & & 1 & 1 & 0 & 1 & 0 & 1 & 1 & 0 & 1 & 1 & 1 & 1 & 1 & 1 & 1 \\
\hline $\begin{array}{l}\text { 1.2. Наявність регіональних } \\
\text { програм чи планів поводження } \\
\text { з відходами чи аналогічних } \\
\text { документів }\end{array}$ & 0 & 2 & 2 & 2 & 0 & 2 & 0 & 0 & 2 & & 0 & 2 & 2 & 2 & 0 & 2 & 0 & 2 & 2 & 0 & 0 & 2 & 0 & 0 & 0 \\
\hline $\begin{array}{l}\text { 1.3. Кількість ТПВ, що } \\
\text { перероблюється (переробка в } \\
\text { якості матеріальних чи інших } \\
\text { ресурсів, у тому числі - } \\
\text { компостування)* }\end{array}$ & 2 & 2 & 2 & 2 & 2 & 0 & 0 & 2 & 4 & & 2 & 2 & 2 & 4 & 0 & 2 & 2 & 2 & 4 & 2 & 0 & 2 & 2 & 2 & 2 \\
\hline $\begin{array}{l}\text { 1.4. Кількість відновлюваних } \\
\text { ТПВ (відновлення енергії)* }\end{array}$ & 0 & 0 & 0 & 0 & 0 & 0 & 0 & 0 & 2 & & 0 & 0 & 0 & 0 & 0 & 0 & 0 & 0 & 0 & 0 & 0 & 0 & 0 & 0 & 0 \\
\hline $\begin{array}{l}\text { 1.5. Кількість ТПВ, що } \\
\text { захоронюються чи спалюються } \\
\text { без відновлення енергії* }\end{array}$ & 2 & 2 & 2 & 2 & 2 & 2 & 0 & 2 & 2 & & 2 & 2 & 2 & 4 & 0 & 2 & 2 & 2 & 4 & 2 & 0 & 2 & 2 & 2 & 2 \\
\hline $\begin{array}{l}\text { 1.6. Розвиток всіх форм } \\
\text { перероблення ТПВ (в тому } \\
\text { числі компостування) }\end{array}$ & 1 & 1 & 0 & 1 & 1 & 0 & 0 & 1 & 0 & & 1 & 0 & 1 & 2 & 0 & 1 & 0 & 1 & 2 & 1 & 0 & 0 & 1 & 1 & 1 \\
\hline $\begin{array}{l}\text { 1.7. Впровадження роздільного } \\
\text { збирання у населених пунктах }\end{array}$ & 1 & 1 & 1 & 1 & 1 & 2 & 1 & 2 & 1 & & 0 & 1 & 1 & 1 & 1 & 1 & 1 & 0 & 2 & 2 & 1 & 1 & 0 & 1 & 1 \\
\hline \multicolumn{26}{|c|}{$\begin{array}{l}\text { 2. } \quad \text { Існування та застосування економічних інструментів для підтримки системи управління відходами у відповідності до } \\
\text { ієрархії методів поводження з відходами }\end{array}$} \\
\hline $\begin{array}{l}\text { 2.1. Приріст фінансування, } \\
\text { спрямованого на розвиток } \\
\text { сфери поводження } 3 \text { відходами }\end{array}$ & 2 & 2 & 0 & 2 & 0 & 0 & 2 & 2 & 2 & & 2 & 2 & 2 & 2 & 0 & 2 & 2 & 2 & 2 & 2 & 2 & 2 & 2 & 2 & 2 \\
\hline 2.2. Плата за захоронення відходів & 1 & 1 & 1 & 0 & 0 & 2 & 1 & 2 & 2 & & 1 & 1 & 2 & 0 & 1 & 0 & 1 & 1 & 2 & 2 & 2 & 1 & 2 & 0 & 2 \\
\hline \multicolumn{26}{|c|}{ 3. $\quad$ Існування та якість належної мережі об’єктів поводження з відходами та планування нових об'єктів } \\
\hline $\begin{array}{l}\text { 3.1. Охоплення населення } \\
\text { послугами зі збирання відходів }\end{array}$ & 0 & 0 & 0 & 0 & 0 & 0 & 0 & 0 & 0 & & 0 & 0 & 0 & 0 & 0 & 0 & 0 & 0 & 0 & 0 & 0 & 0 & 0 & 0 & 0 \\
\hline $\begin{array}{l}\text { 3.2. Доступність достатніх } \\
\text { потужностей переробних } \\
\text { підприємств (включаючи } \\
\text { розміщення та спалювання) }\end{array}$ & 0 & 0 & 0 & 0 & 0 & 0 & 0 & 0 & 0 & & 0 & 0 & 0 & 0 & 0 & 0 & 0 & 0 & 0 & 0 & 0 & 0 & 0 & 0 & 0 \\
\hline $\begin{array}{l}\text { 3.3. Прогнозування утворення } \\
\text { ТПВ та потреби в переробних } \\
\text { потужностях }\end{array}$ & 0 & 0 & 0 & 0 & 0 & 0 & 0 & 0 & 0 & & 0 & 0 & 0 & 0 & 0 & 0 & 0 & 0 & 0 & 0 & 0 & 0 & 0 & 0 & 0 \\
\hline $\begin{array}{l}\text { 3.4. Існування та якість } \\
\text { планування утворення ТПВ та } \\
\text { їх перероблення в програмах та } \\
\text { планах поводження з відходами }\end{array}$ & 0 & 0 & 0 & 0 & 0 & 0 & 0 & 0 & 1 & & 0 & 0 & 1 & 0 & 0 & 0 & 0 & 0 & 0 & 0 & 0 & 0 & 0 & 0 & 0 \\
\hline $\begin{array}{l}\text { 3.5. Відповідність існуючих } \\
\text { полігонів вимогам нормативно- } \\
\text { правових актів }\end{array}$ & 0 & 0 & 0 & 0 & 0 & 0 & 0 & 0 & 0 & & 0 & 0 & 0 & 0 & 0 & 0 & 0 & 0 & 0 & 0 & 0 & 0 & 0 & 0 & 0 \\
\hline \multicolumn{26}{|c|}{$4 . \quad$ Зменшення частки захоронення відходів, що підлягають біологічному розпаду } \\
\hline $\begin{array}{l}\text { 4.1. Досягнення цільових } \\
\text { показників щодо захоронення } \\
\text { відходів, які біологічно } \\
\text { розкладаються }\end{array}$ & 1 & 0 & 0 & 0 & 0 & 0 & 0 & 0 & 0 & & 0 & 0 & 0 & 0 & 0 & 0 & 0 & 0 & 0 & 0 & 0 & 1 & 0 & 0 & 0 \\
\hline Всього & 11 & 11 & 9 & 11 & 6 & 8 & 4 & 11 & 17 & 7 & 9 & 11 & 13 & 16 & 2 & 11 & 9 & 10 & 19 & 12 & 6 & 12 & 10 & 9 & 11 \\
\hline
\end{tabular}

Довідка: розробка авторів 
При розрахунку загального бала індикатори $1.3,1.4,1.5$ подвоювались для врахування їх важливості при організації ефективної комплексної системи управління відходами.

Рівень розриву між захороненням ТПВ (тверді побутові відходи) та рівнем економічного розвитку регіонів оцінювався за результатами попередніх досліджень [22]. Так для регіонів України характерні три типи декаплінгу, при чому, всі є такими, що характеризують складну еколого-економічну ситуацію на регіональному рівні та в країні в цілому: негативний абсолютний декаплінг, негативний відносний декаплінг та негативний зворотний декаплінг.

В 11 областях затверджені регіональні програми поводження з відходами, про що $є$ інформація на сайті Міністерства екології і природних ресурсів [17] та у звіті Антимонопольного комітету України [18], а також міжнародної благодійної організації «Екологія - право - людина» [16], в ряді областей розроблені проекти програм, проте їх затвердження не відбулося, тому вони мають неофіційний характер та не можуть бути підставами для здійснення заходів з удосконалення систем поводження з відходами в області. В ряді областей (наприклад, в Харківській), розроблені програми відсутні у вільному доступі (в такому випадку даний індикатор також оцінювався в 0 балів).

Перевезення зібраних ТПВ в Україні здійснюється на об'єкти оброблення та перероблення відходів (заготівельні пункти вторинної сировини, сміттєпереробні підприємства, ділянки компостування, сміттєспалювальні заводи) та на місця видалення (полігони або звалища). Частка ТПВ, що направляється на перероблення, обчислена на основі даних про обсяги відходів, що потрапляють на об’єкти оброблення та перероблення по відношенню до загальної кількості перевезених відходів. Також враховано, що після сортування ТПВ на сміттєпереробних підприємствах залишок ТПВ також направляється на захоронення. У 2018 році частка ТПВ, що направляється на перероблення по областях України, варіюється від $20 \%$ (Миколаївська область) до 0 \% (Одеська, Херсонська, Запорізька). При цьому при встановленні балів до уваги взято цільовий показник перероблення відходів у 2018 році (за Національною стратегією управління відходами до 2030 року [12]), який становить $5 \%$. Отже, регіони, які у 2018 році перевищували це значення, отримували 2 бали, області, які в 2018 році перероблювали $0 \%$ своїх ТПВ отримували 0 балів, решта -1 бал.

Виробництво енергії з ТПВ в Україні здійснюється на сміттєспалювальному заводі «Енергія», який знаходиться в м. Київ. Крім нього спалювання відходів здійснюється на двох сміттєспалювальних установках в м. Харків та на одній в м. Люботин Харківської області. Ці установки здійснюють утилізацію відходів тільки для підприємств ДП «Південна залізниця». За інформацією звітності 1-ТПВ за 2018 рік електро- чи теплоенергія на них не вироблялась. Тому даний показник $є$ не нульовим (близько $1 \%$ лише для Київської області.

У 2018 році в усіх регіонах України абсолютна більшість ТПВ захоронюється на полігонах чи звалищах, частка відходів, що підлягають депонуванню, лежить в діапазоні від 80 до $100 \%$. При встановлення порогових значень враховувався цільовий показник захоронення відходів у 2018 році $80 \%$.

Темпи розвитку сектора перероблення ТПВ оцінювалися по відношенню до обсягів перероблення у 2015. При цьому в 4 областях зафіксовано зниження темпів перероблення в 2018 році, порівняно 32015. Максимальне зростання даного сектору за вказаний час становить $20 \%$ та спостерігається у Миколаївській області.

Впровадження роздільного збирання ТПВ у населених пунктах оцінювалось як частка населених пунктів, у яких впроваджено роздільне збирання ТПВ від загальної кількості населених пунктів регіону у відсотках. В цілому по Україні роздільне збирання ТПВ здійснюється в 4 \% населених пунктів. Залежно від регіону цей показник коливається від 30 \% (Закарпатська область) до 0,5 \% (Сумська область).

Розвиток системи фінансування сфери поводження з відходами оцінювався по відношенню до аналогічних показників у 2015 році. Темпи приросту фінансування оцінювались у перерахунку на одну особу в цінах 2015 року з урахуванням індексу споживчих цін. За результатами розрахунків у чотирьох областях фіксується негативна динаміка, тобто зниження фінансування. Решта регіонів показують позитивний приріст фінансування на 1 особу (рис. 1). 


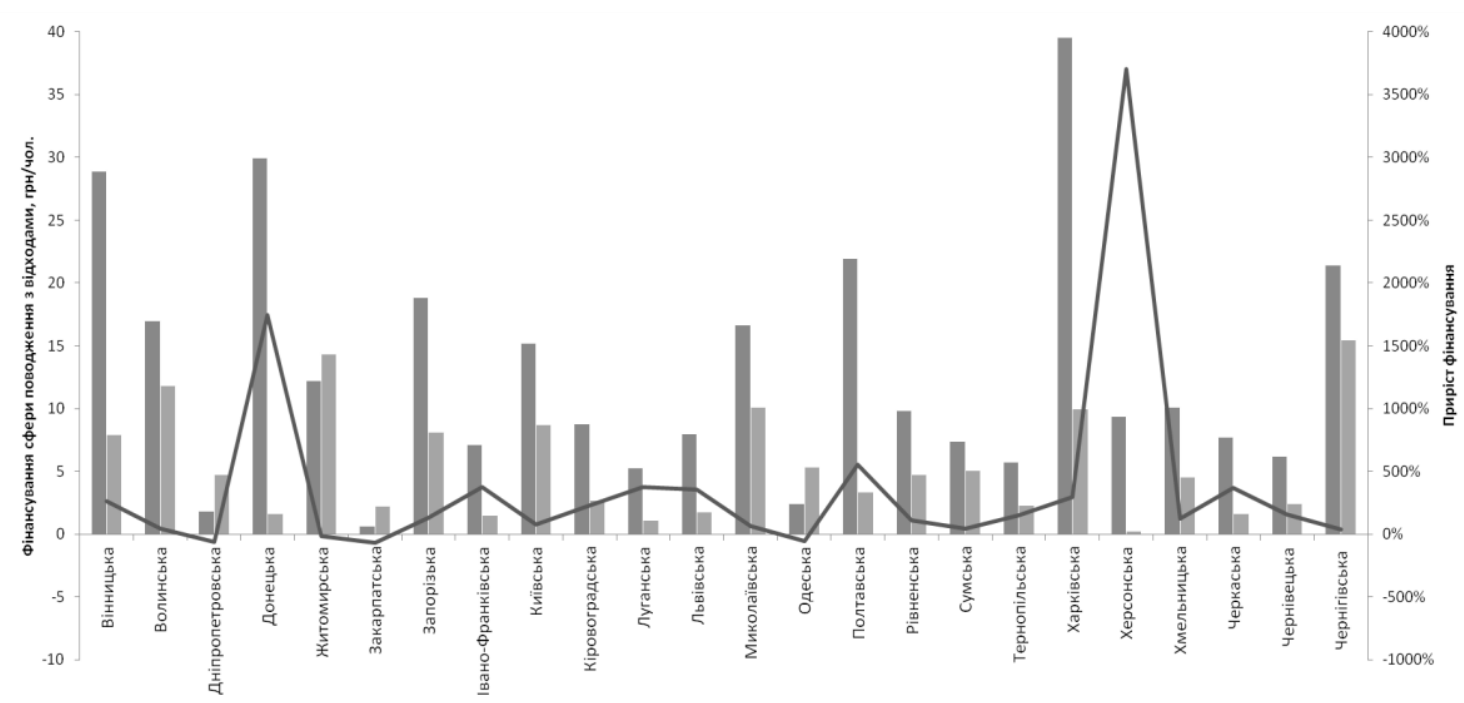

- фінансування сфери поводження з відходами у 2018 р (у щінах 2015 р.), грн/чол. — Фінансування сфери поводження з відходами у 2015 р., грн/чол.

—Приріст фінансування, \%

Рис. 1. Динаміка показників фінансування сфери поводження з відходами в регіонах Украӥни

У роботі використано значення середніх тарифів для населення за захоронення відходів (грн/ $\left.\mathbf{M}^{3}\right)$, яке

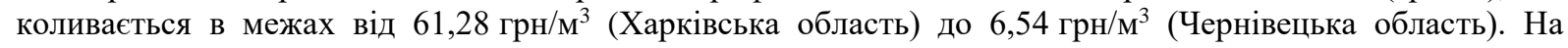
графіку (рис. 2) зображено диспропорцію в регіонах України (для тих з них, які мають дані, що можна зіставити) за величиною тарифів на захоронення відходів для різних суб’єктів.

Варто підкреслити низьку якість даних, що публікуються в цій сфері: часто не вказуються одиниці вимірювання, або їх неможливо порівняти (так тарифи в сфері поводження 3 відходами можуть

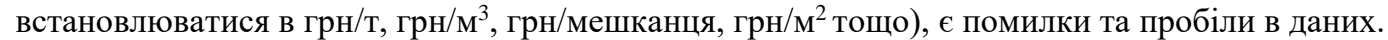

Як видно з графіків, існує значна розбіжність між величиною максимальних та мінімальних тарифів в межах окремих регіонів. Так, наприклад, в Одеській області різниця між максимальним та мінімальним тарифом на захоронення ТПВ для населення складає понад 210 грн/м ${ }^{3}$, в Тернопільській - понад 140 грн/ $\mathrm{M}^{3}$.

Жоден регіон України не досяг 100 \% охоплення населення послугами з вивезення відходів. Таке значення показників на сьогодні декларується лише в деяких містах (наприклад, Київ, Харків тощо). Проте через низький рівень розвитку системи поводження з відходами в сільській місцевості середні показники по областях знаходяться в діапазоні від 95 \% (Миколаївська) до 61 \% (Волинська). Даний індикатор є вирішальним для оцінки адекватності існуючої інфраструктури збирання відходів. Якщо відходи збираються неналежним чином та не досягається 100 \% охоплення населення, то такі відходи 3 високим ступенем ймовірності будуть видалені екологічно небезпечним способом (на несанкціоноване звалище, у водні об’єкти, шляхом спалення тощо), що в цілому призводить до заперечення про утворення відходів з боку населення, шкідливого впливу на довкілля, втрати цінних ресурсів.

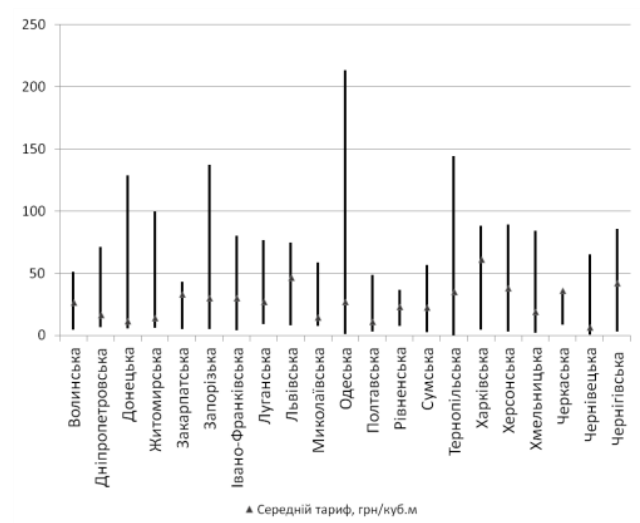

a)

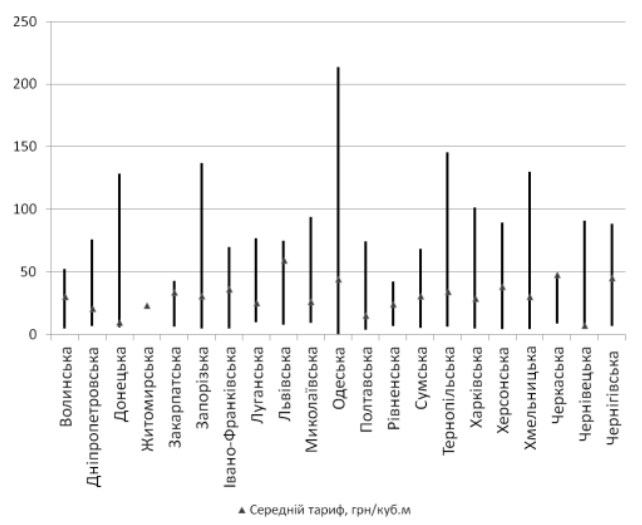

б) 


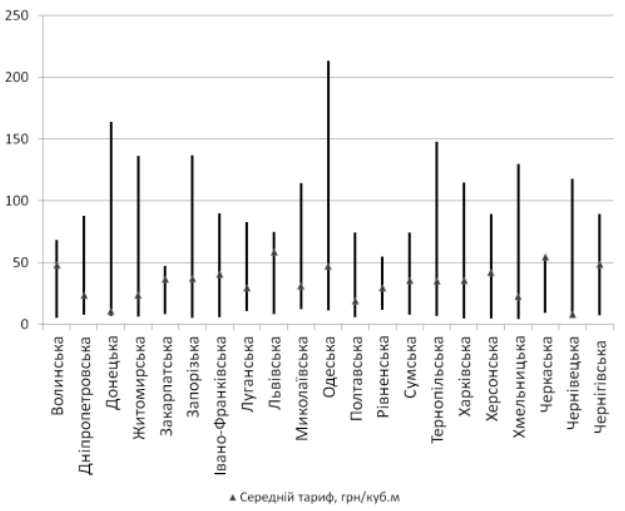

в)

Рис. 2. Тарифи на захоронення відходів в регіонах Украӥни (а-тарифи для населення, б - тарифи для бюджетних організачій, в - тарифи для інших споживачів)

Належна інфраструктура оброблення та перероблення відходів, а також наявність достатніх потужностей для перероблення побутових відходів є базовою та обов'язковою умовою для екологічно безпечної та ефективної комплексної системи управління відходами. Крім того, функціонування таких об'єктів має здійснюватися з урахуванням прогнозів утворення відходів, зміни їх морфологічного складу та інших показників.

Прогнозування утворення ТПВ та потреби в переробних потужностях знаходиться на дуже низькому рівні в Україні. Фактично ні регіональні програми, ні інші документи в сфері поводження з відходами не містять такої інформації, що свідчить про вкрай низький рівень стратегічного планування даного питання. Частково планування потужностей 3 перероблення відходів відображене в Програмі поводження з твердими відходами у Київській області на 2017-2020 роки [23] та Стратегії управління відходами у Львівській області до 2030 року [24].

У своєму щорічному звіті «Стан сфери поводження з відходами в Україні» за 2018 рік, Міністерство регіонального розвитку, будівництва та житлово-комунального господарства стверджує, що $16 \% 3$ понад 6 тис. полігонів та звалищ не відповідає нормам екологічної безпеки. Згідно з чинною нормативною базою, забороняється проектування, будівництво та експлуатація полігонів побутових відходів без оснащення системами захисту грунтових вод, вилучення та знешкодження біогазу та фільтрату [15]. На полігон побутових відходів мають бути розроблені паспорт місця видалення відходів, щорічні технологічні плани організації робіт із захоронення відходів. Відходи, що розміщуються на полігоні, повинні бути розрівнені, ущільнені та укриті ізолювальним шаром. Полігони мають бути обладнані системою моніторингу, суцільною огорожею або грунтовим валом по всьому периметру, шлагбаумом чи в їзними воротами при в’їзді, повинні проводитися природоохоронні заходи, спрямовані на захист компонентів довкілля.

За інформацією щодо полігонів/звалищ побутових відходів в Україні, опублікованою на сайті Міністерства регіонального розвитку, будівництва та житлово-комунального господарства від 21.05.2018 p. за результатами моніторингу [14], тільки за ознакою наявності систем збирання i знезараження фільтрату не відповідають чинним нормам понад 90 \% місць видалення відходів (для двох областей - Київської та Закарпатської інформація $є$ неповною). Ситуація щодо існуючих полігонів за регіонами (на підставі офіційної інформації) проілюстрована на рисунку 3.

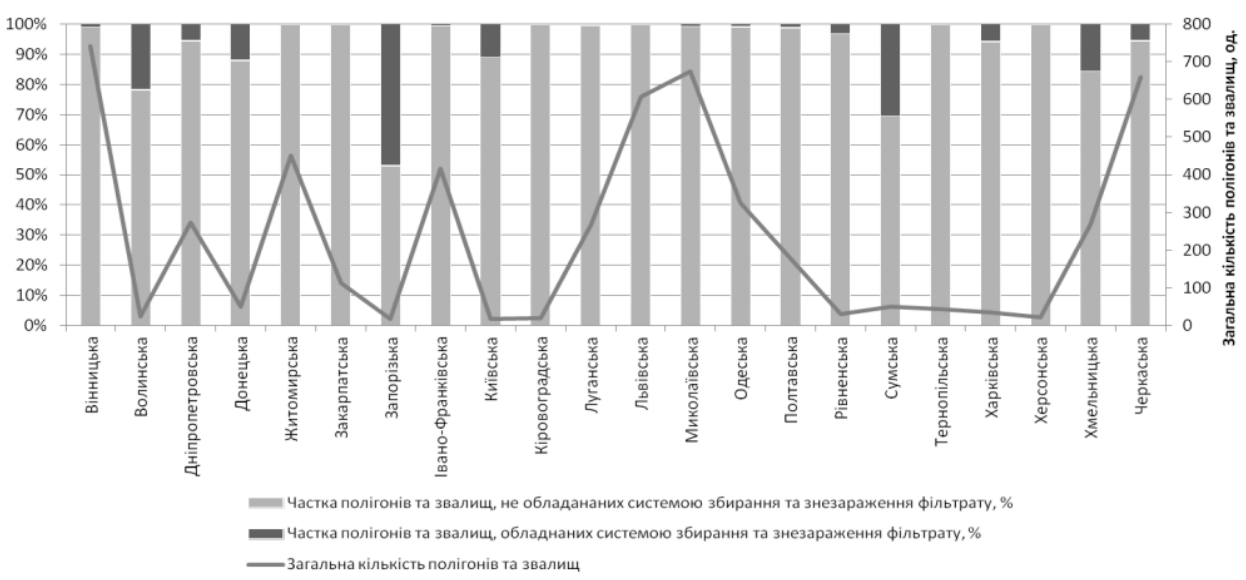

Рис. 3. Обладнання полігонів системою збирання та знезараження фільтрату 
Національна стратегія управління відходами до 2030 року передбачає зменшення обсягів захоронення побутових відходів, що біологічно розкладаються. Так одним із цільових показників Стратегії є створення потужностей $з$ компостування біовідходів. На сьогодні інформація про сортування відходів, що біологічно розкладаються, не збирається. Оцінка даного показника здійснювалась за даними Міністерства регіонального розвитку, будівництва та житлово-комунального господарства, згідно 3 якими у 2018 році на ділянки компостування транспортувалися лише ТПВ, зібрані у Вінницькій та Хмельницькій областях, проте їх частка є незначною (менше 1 \% від обсягів збирання).

Результати оцінювання регіонів за рівнем розвитку системи управління побутовими відходами на основі методики BiPRO наведені на діаграмі (рис. 4).

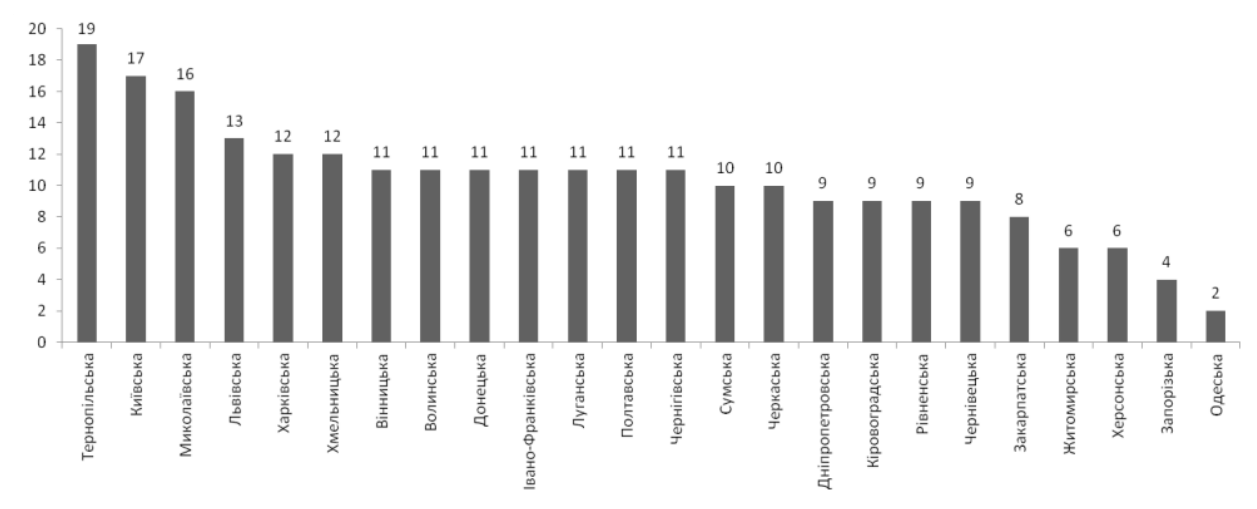

Рис. 4. Регіони України за ефективністю системи управління побутовими відходами

Як видно з рисунка 4, найвищий рівень розвитку системи поводження з відходами характерний для Тернопільської, Київської та Миколаївської областей. Найнижчий рівень визначено для Херсонської, Житомирської, Запорізької та Одеської областей. При цьому варто зазначити, що максимально можливий показник розвитку системи управління відходами за даною методикою для регіонів України складає 36 балів. Як бачимо, найкращі за розвитком регіони набирають тільки близько половини від максимально можливої оцінки.

Діаграма на рисунку 5 відображає суму індикаторів за всіма дослідженими регіонами, що дозволяє оцінити найрозвиненіші та найслабші аспекти системи управління відходами в цілому по Україні.

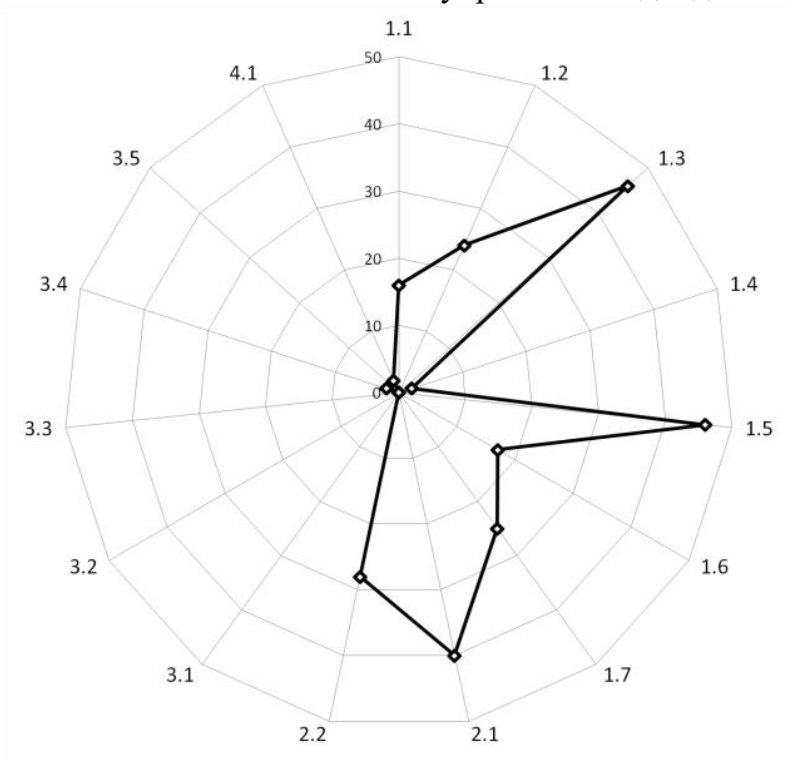

Рис. 5. Загальний ступінь розвитку показників сфери поводження з відходами

Висновки та перспективи подальших досліджень. Система управління побутовими відходами на всій території України характеризується невисокою ефективністю. До найбільш слабких аспектів ії функціонування можна зарахувати показники групи 3 - існування та якість належної мережі об'єктів поводження з відходами та планування нових об'єктів. Так існує потреба в підприємствах, на яких здійснюється оброблення та перероблення ТПВ, важливим є приведення місць видалення відходів у відповідність до вимог нормативно-правових актів. Потребує уваги повне охоплення населення 
послугами зі збирання відходів, а також прогнозування та планування показників у сфері поводження 3 відходами для вироблення стратегічних довгострокових рішень.

Отримані результати показали також наявність відмінностей на регіональному рівні в системах управління відходами. Збалансований розвиток всіх регіонів дозволить забезпечити належне функціонування системи управління відходами на національному рівні.

Проведений аналіз продемонстрував можливості даної методики для проведення порівняльного аналізу регіонів щодо рівня розвитку системи управління відходами, а також для виявлення слабких сторін такої системи. Індикатори, що використовуються для оцінювання, характеризують технічні, економічні та організаційні аспекти функціонування системи. Удосконалення системи управління відходами має забезпечуватися шляхом ефективного й раціонального планування та прогнозування основних показників сфери поводження з відходами та їх відображення в регіональних програмах i планах, розвитком сучасних технологій та інфраструктури оброблення й перероблення відходів, збалансуванням фінансово-економічних механізмів тощо.

\section{Список використаної літератури:}

1. Wasteaware'benchmark indicators for integrated sustainable waste management in cities / D.C. Wilson, L.Rodic, M.J. Cowing and other // Waste Management. - 2015. - № 35. - P. 329-342. doi.org/10.1016/j.wasman.2014.10.006.

2. Comparative analysis of solid waste management in 20 cities / D.C. Wilson, L.Rodic, A.Scheinberg and other // Waste Management \& Research. - 2012. - № 30 (3). - P. 237-254. - doi: 10.1177/0734242X12437569.

3. Sanjeevi $V$. Development of performance indicators for municipal solid waste management (PIMS): A review / V.Sanjeevi, P.Shahabudeen // Waste Management \& Research. - 2015. - № 33 (12). - P. 1052-1065. doi: $10.1177 / 0734242 \times 15607428$.

4. Environmental assessment of solid waste systems and technologies: EASEWASTE / J.T. Kirkeby, T.L. Hansen, H.Birgisdóttir and other // Waste Manag Res. - 2006. - Vol. 24. - P. 3-15.

5. Using indicators as a tool to evaluate municipal solid waste management: A critical review / D.E.T. Cervantes, A.L. Martínez, M.C. Hernández, A.L.G. de Cortázar // Waste management. - 2018. - № 80. - P. 51-63. doi.org/10.1016/j.wasman.2018.08.046.

6. ванюта С.П. Екологічна безпека регіонів України: порівняльні оцінки / С.П. Іванюта, А.Б. Качинський // Стратегічні пріоритети. - 2013. - № 3. - С. 157-164.

7. Коваленко А.О. Методичні підходи до визначення потенціалу екологічної модернізації регіонів України / А.О. Коваленко // Вісник Приазовського Державного Технічного Університету. - 2016. - № 32. - С. 49-55. doi.org/10.31498/2225-6725.32.2016.105135.

8. Писаренко П.В. Оцінка та прогнозування ресурсно-екологічної безпеки в контексті сталого розвитку регіонів України / П.В. Писаренко, М.С. Самойлік, Л.А. Колєснікова // Вісник Дніпропетровського державного аграрно-економічного Університету. - 2017. - № 3 (45). - С. 5-10.

9. Стегней M.I. Екологічний компонент у системі сталого регіонального розвитку / M.I. Cтегней, А.-М.І. Архангельська // Економіка та суспільство. - Мукачево, 2017. - № 9. - С. 798-802.

10. Інноваційне підприємництво в сфері поводження 3 побутовими відходами: міжнародний контекст i регіональні особливості України / І.А. Островський, С.Ю. Юр'єва, О.П. Коюда, О.І. Славута // Інвестиції: практика та досвід. - 2019. - № 12. - С. 16-21. - doi: 10.32702/2306-6814.2019.12.16.

11. Кривенко C.В. Проблеми вдосконалення системи управління сферою поводження з твердими побутовими відходами: регіональний аспект / С.В. Кривенко // Управління розвитком. - 2015. - № 2. - С. 12-19.

12. Національна стратегія управління відходами в Україні до 2030 року. База даних «Законодавство України»/ BP України [Електронний ресурс]. - Режим доступу : https://zakon.rada.gov.ua/laws/show/820-2017-\%D1\%80.

13. Стан сфери поводження 3 побутовими відходами в Україні / Міністерство регіонального розвитку, будівництва та житлово-комунального господарства України [Електронний ресурс]. - Режим доступу : http://www.minregion.gov.ua/napryamki-diyalnosti/zhkh/terretory.

14. Інформація щодо полігонів/звалищ побутових відходів в Україні / Міністерство регіонального розвитку, будівництва та житлово-комунального господарства України [Електронний ресурс]. - Режим доступу : http://www.minregion.gov.ua/napryamki-diyalnosti/zhkh/terretory/informatsiya-shhodo-poligoniv-zvalishhpobutovih-vidhodiv-v-ukrayini/.

15. ДБН В.2.4-2-2005 Полігони твердих побутових відходів. Основні положення проектування. - К. : Держбуд України, 2005. - 33 с.

16. Аналітичний звіт про аналіз обласних програм поводження з відходами / за заг. ред. О.Кравченко. - Львів, Манускрипт, 2019. - 52 с. [Електронний ресурс]. - Режим доступу : http://epl.org.ua/wpcontent/uploads/2019/07/2533_EPL_Analituchnuy_zvit_vidhodu_NET.pdf?fbclid=IwAR1 yqj ZLgkqRAO3QeYr7PCY1eno2Dn33Se3J1TxWm3bWhgJirinmwxGEcEw.

17. Перелік діючих регіональних природоохоронних програм і тих, що розроблялись в областях у 2017 році [Електронний ресурс]. - Режим доступу : https://cutt.ly/TeLCBpY.

18. Звіт за результатами дослідження ринків послуг у сфері поводження з побутовими відходами. - К. : Антимонопольний комітет України, 2018. [Електронний ресурс]. - Режим доступу http://www.amc.gov.ua/amku/control/main/uk/doccatalog/list?currDir=98212\&\&documentList_stind=21.

19. Screening of waste management performance of EU Member States. Report submitted under the EC project "Support to Member States in improving waste management based on assessment of Member States' performance". 
Report prepared for the European Commission. - DG ENV, July 2012. - 49 р. [Електронний ресурс]. - Режим доступу : https://ec.europa.eu/environment/waste/studies/pdf/Screening_report.pdf.

20. BiPRO/CRI. Assessment of separate collection schemes in the 28 capitals of the EU. Final report. - 2015 [Електронний ресурc]. https://ec.europa.eu/environment/waste/studies/pdf/Separate\%20collection_Final\%20Report.pdf.

21. Хандогіна O.B. Методика комплексної оцінки рівня розвитку системи управління побутовими відходами на регіональному рівні / О.В.Хандогіна // Вісник КрНУ імені Михайла Остроградського. - 2019. - № 5 (118). C. 40-45. - doi: 10.30929/1995-0519.2019.5.40-45.

22. Мущиинська Н.Ю. Декаплінг-аналіз в оцінці системи управління твердими побутовими відходами в регіонах України / Н.Ю. Мущиинська, О.В. Хандогіна // Modern Economics. - 2019. - № 16. - С. 100-107. https://doi.org/10.31521/modecon.V16(2019)-15.

23. Програма поводження з твердими побутовими відходами у Київській області на 2017-2020 роки. [Електронний pecypc]. - Режим доступу : http://koda.gov.ua/normdoc/pro-skhvalennya-proektu-programi-povod-2/ .

24. Стратегія управління відходами у Львівській області до 2030 року [Електронний ресурс]. - Режим доступу : http://gw1.oblrada.lviv.ua/rada/rishennialor.nsf/52889c345440ab40c2257b55007e8f51/7ccf6ba2bc2c5a79c225820 300531eb7/\$FILE/580_dod.pdf.

\section{References:}

1. Wilson, D.C., Rodic, L., Cowing, M.J., Velis, C.A., Whiteman, A.D., Scheinberg, A., Vilches, R., Masterson, D., Stretz, J. and Oelz, B. (2015), «Wasteaware'benchmark indicators for integrated sustainable waste management in cities», Waste Management,Vol. 35, pp. 329-342, doi.org/10.1016/j.wasman.2014.10.006.

2. Wilson, D.C., Rodic, L., Scheinberg, A., Velis, C.A. and Alabaster, G. (2012), «Comparative analysis of solid waste management in 20 cities», Waste Management \& Research, Vol. 30 (3), pp. 237-254, doi: $10.1177 / 0734242 X 12437569$.

3. Sanjeevi, V. and Shahabudeen, P. (2015), «Development of performance indicators for municipal solid waste management (PIMS): A review», Waste Management \& Research, Vol. 33 (12), pp. 1052-1065, doi: $10.1177 / 0734242 \times 15607428$.

4. Kirkeby, J.T., Hansen, T.L., Birgisdóttir. H., Bhander. G.S., Hauschild, M.Z. and Christensen, T.H. (2006), «Environmental assessment of solid waste systems and technologies: EASEWASTE», Waste Manag Res., Vol. 24, pp. 3-15.

5. Cervantes, D.E.T., Martínez, A.L., Hernández, M.C. and de Cortázar, A.L.G. (2018), «Using indicators as a tool to evaluate municipal solid waste management: A critical review», Waste management, Vol. 80, pp. 51-63, doi.org/10.1016/j.wasman.2018.08.046.

6. Ivanjuta, S.P., and Kachyns'kyj, A.B. (2013), «Ekologichna bezpeka regioniv Ukrai'ny: porivnjal'ni ocinky», Strategichni priorytety, No. 3, pp. 157-164.

7. Kovalenko, A.O. (2016), «Metodychni pidhody do vyznachennja potencialu ekologichnoi' modernizacii' regioniv Ukrai'ny», Visnyk Pryazovs'kogo Derzhavnogo Tehnichnogo Universytetu, No. 32, pp. 49-55.

8. Pysarenko, P.V., Samojlik, M.S. and Koljesnikova, L.A. (2017), «Ocinka ta prognozuvannja resursno-ekologichnoi' bezpeky v konteksti stalogo rozvytku regioniv Ukrai'ny», Visnyk Dnipropetrovs'kogo derzhavnogo agrarnoekonomichnogo Universytetu, No. 3 (45), pp 5-10.

9. Stegnej, M.I. and Arhangel's'ka, A.-M.I. (2017), «Ekologichnyj komponent u systemi stalogo regional'nogo rozvytku», Ekonomika ta suspil'stvo, Mukachevo, No. 9, pp. 798-802.

10. Ostrovs'kyj, I.A., Jur'jeva, S.Yu., Kojuda, O.P. and Slavuta, O.I. (2019), «Innovacijne pidpryjemnyctvo v sferi povodzhennja z pobutovymy vidhodamy: mizhnarodnyj kontekst i regional'ni osoblyvosti Ukrai'ny», Investytsiyi: praktyka ta dosvid, No. 12, pp. 16-21, doi: 10.32702/2306-6814.2019.12.16.

11. Kryvenko, S.V. (2015), «Problemy vdoskonalennja systemy upravlinnja sferoju povodzhennja z tverdymy pobutovymy vidhodamy: regional'nyj aspekt», Upravlinnja rozvytkom, No. 2, pp. 12-19.

12. «Nacional'na strategija upravlinnja vidhodamy $\mathrm{v}$ Ukrai'ni do 2030 roku», [Online], available at: https://zakon.rada.gov.ua/laws/show/820-2017-\%D1\%80.

13. «Stan sfery povodzhennja $\mathrm{z}$ pobutovymy vidhodamy $\mathrm{v}$ Ukrai'ni», [Online], available at: http://www.minregion.gov.ua/napryamki-diyalnosti/zhkh/terretory

14. «Informacija shhodo poligoniv/zvalyshh pobutovyh vidhodiv $\mathrm{v}$ Ukrai'ni»: [Online], available at: http://www.minregion.gov.ua/napryamki-diyalnosti/zhkh/terretory/informatsiya-shhodo-poligoniv-zvalishhpobutovih-vidhodiv-v-ukrayini/

15. Derzhbud Ukrai'ny (2005), «DBN V.2.4-2-2005 Poligony tverdyh pobutovyh vidhodiv. Osnovni polozhennja proektuvannja», Derzhbud Ukrai'ny, Kyi'v, 33 p.

16. Kravchenko, O. (ed.) (2019), «Analitychnyj zvit pro analiz oblasnyh program povodzhennja z vidhodamy», Kompanija «Manuskrypt, L'viv, 52 p., [Online], available at: http://epl.org.ua/wpcontent/uploads/2019/07/2533_EPL_Analituchnuy_zvit_vidhodu_NET.pdf?fbclid=IwAR1 yqjZLgkqRAO3QeYr7P CY1eno2Dn33Se3JITxWm3bWhgJirinmwxGEcEw

17. «Perelik dijuchyh regional'nyh pryrodoohoronnyh program i tyh, shho rozrobljalys' v oblastjah u 2017 roci», [Online], available at: https://cutt.ly/TeLCBpY

18. Antymonopol'nyj komitet Ukrai'ny (2018), «Zvit za rezul'tatamy doslidzhennja rynkiv poslug u sferi povodzhennja $\mathrm{z}$ pobutovymy vidhodamy», Kyi'v, [Online], available at: http://www.amc.gov.ua/amku/control/main/uk/doccatalog/list?currDir=98212\&\&documentList_stind=21 
19. BiPRO (2012), «Screening of waste management performance of EU Member States. Report submitted under the EC project «Support to Member States in improving waste management based on assessment of Member States' performance». Report prepared for the European Commission», DG ENV, [Online], available at: https://ec.europa.eu/environment/waste/studies/pdf/Screening_report.pdf

20. BiPRO/CRI (2015), «Assessment of separate collection schemes in the 28 capitals of the EU. Final report», [Online], available at: https://ec.europa.eu/environment/waste/studies/pdf/Separate\%20collection_Final\%20Report.pdf

21. Khandogina, O.V. (2019), «Metodyka kompleksnoi' ocinky rivnja rozvytku systemy upravlinnja pobutovymy vidhodamy na regional'nomu rivni», Visnyk KrNU imeni Myhajla Ostrograds'kogo, No. 5 (118), pp. 40-45, doi: 10.30929/1995-0519.2019.5.40-45.

22. Mushchynska, N.Yu. and Khandogina, O.V. (2019), «Dekapling-analiz v ocinci systemy upravlinnja tverdymy pobutovymy vidhodamy v regionah Ukrai'ny», Modern Economics, No 16, pp. 100-107, doi.org/10.31521/modecon.V16(2019)-15.

23. «Programa povodzhennja z tverdymy pobutovymy vidhodamy u Kyi'vs'kij oblasti na 2017-2020 roky», [Online], available at: http://koda.gov.ua/normdoc/pro-skhvalennya-proektu-programi-povod-2/

24. «Strategija upravlinnja vidhodamy u L'vivs'kij oblasti do 2030 roku», [Online], available at: http://gw1.oblrada.lviv.ua/rada/rishennialor.nsf/52889c345440ab40c2257b55007e8f51/7ccf6ba2bc2c5a79c225820 300531eb7/\$FILE/580_dod.pdf

Хандогіна Ольга Вадимівна - старший викладач кафедри інженерної екології міст Харківського національного університету міського господарства імені О.М. Бекетова.

http://orcid.org/0000-0002-1100-5267

Наукові інтереси:

- системи управління побутовими відходами на регіональному рівні.

E-mail: ol.khandogina@gmail.com.

Мущинська Наталія Юріївна - кандидат економічних наук, доцент, доцент кафедри управління проектами в міському господарстві та будівництві Харківського національного університету міського господарства імені О.М. Бекетова.

http://orcid.org/0000-0001-6294-9180

Наукові інтереси:

- управління територіальним розвитком.

E-mail: muschinska@gmail.com. 